\title{
Conceptualising the Effects of Imprisonment on Families: Collateral Consequences, Secondary Punishment, or Symbiotic Harms?
}

\section{Introduction}

As social scientists, how we talk about and describe the lives of the people we study matters and indeed can contribute to their lived experience. The notion of the consequences of social reaction to naming or labelling has been entrenched in theoretical criminology for decades. This article aims to explore new ways of conceptualising the effects of imprisonment on families of prisoners. We suggest that the language which has most commonly been employed to describe these harms may have contributed to their exclusion from scholarly accounts of punishment. As Garland has argued: "The institutional framework of modern penology tends to narrow our perceptions of the phenomenon and obscure the social ramifications of punishment" (Garland, 1990: 1).

For punishment theorists to more explicitly engage with the effects of punishment on families we may need new terminology. In this paper, we suggest a new analytical approach that might help to facilitate greater engagement and integration of what have until now been two distinct bodies of scholarship: the body of punishment theory that considers the collateral consequences of punishment for prisoners themselves, and the body of criminological work on the harms wrought by imprisonment on families. Currently there is little connection or dialogue between the two but as the field of prisoners' families research is growing rapidly in size and depth it should be seen as an integral part of wider debates about the reach and nature of punishment in society. In order to achieve this aim, greater clarity in how we conceptualise and describe what happens to families of prisoners is needed.

Our approach draws upon and consolidates a rich body of previous research in the field which provides strong evidence of the effects of imprisonment on families. In this paper we consider the ways in which these effects have been understood within current scholarship, before suggesting a new analytical approach. The effects on families have often been gathered under the term 'collateral consequences', but as we will explore in the paper, this term has other meanings and lacks precision and sufficiency for this purpose. Another way such effects are understood is as a form of secondary punishment which attaches to the family member because of the offender. We 
suggest that understanding or explaining the harms in this way prevents proper theorising of the harms, as they are not 'punishment' in the legal sense, but a punishing experience. We propose that the harms experienced by prisoners' families can be more fully described by a term which focuses specifically on the domain of the family, and encompasses their relational, mutual, nonlinear, agentic, and heterogeneous properties, without naming them as incidental, collateral or neutral. To that end we offer the term 'symbiotic harms' as a useful conception which will allow scholars to better capture and analyse the effects on individuals when a family member is imprisoned.

For the purposes of this paper 'prisoners' families' are those who have kin relationships with a person serving a sentence of imprisonment. They may be partners and children, or parents, siblings and other relatives, although 'quasi' kin such as close friends might also be important here. We are looking specifically at the harms linked to sentences of imprisonment, rather than those which come about from criminal justice contact or supervision more generally. Although we do not consider it within this paper, we do think that the analysis we propose could extend to the harms linked to arrest, trial, and community sanctions. There is much that could be said about prisoners' families' interactions with the 'shadow carceral state' (Beckett \& Murakawa, 2012), but that too is beyond the scope of this article.

\section{The harms experienced by families of prisoners}

In the past decade there has been a widening and deepening of the research literature on prisoners' families. The scholarship on the impact of family member imprisonment indicates that such imprisonment may cause a non-imprisoned family member to experience a range of negative effects, including exclusionary and stigmatizing practices, lost friendships, financial stress, direct abuse and attacks, disrupted attachments, reduced life chances, disrupted education and employment, and an increased risk of mental health and addiction problems (e.g. see Travis and Waul, 2004; Comfort, 2007; Murray and Farrington, 2008; Dallaire and Wilson, 2010; Sampson, 2011; Smith 2014 ; Wakefield and Wildeman, 2011; Arditti, 2012; ; Wakefield and Wildeman, 2014; Halsey and Deegan 2015; Besemer and Dennison, 2017; Minson and Condry, 2015; Minson, 2018; Condry and Smith 2018). Family members are affected as individuals and as citizens, experiencing broader patterns of marginalisation and discrimination that compound and connect 
to pre-existing forms such as racial, economic and gender inequality. The harms of imprisonment sustain and reproduce patterns of inequality, have a profound impact upon the social fabric and organisation of society both in the current context and in the future, and affect the way in which we perceive the place of individuals in a democratic society. As Western has argued, prisons and jails in the US have 'come to form part of a novel system of social inequality' (Western, 2006, p. xi). Whether we understand social justice to be primarily achieved through equality of citizens in resources or democratic participation; access to capabilities and substantive freedoms (Nussbaum, 2011; Sen, 1999); freedom from institutional oppression and domination (Young, 1990); or political liberties and participatory citizenship, the families of prisoners are restricted on all accounts (Condry, 2018).

This intersects strikingly with race: Wakefield and Wildeman show that African Americans born around 1990 had a one in four risk of parental imprisonment by the time they reached the age of fourteen, compared with a risk of one in thirty for white children. (Wakefield and Wildeman, 2014). Lee et al (2015) use 2006 General Social Survey data to provide national estimates of connectedness to prisoners in the US of $44 \%$ of black women (and 32\% of black men) and 12\% of white women (and 6\% of white men). Punishment also intersects with race in European countries where black and minority ethnic groups are disproportionately represented in the prison population - in the UK 26\% of all prisoners (Ministry of Justice, 2017) compared to 1 in 11 of the general population at the last census (Office for National Statistics, 2011). In Australia, Aboriginal and Torres Strait Islander prisoners account for over a quarter $(27 \%)$ of the total Australian prisoner population, compared to $2 \%$ of the general Australian population aged 18 years and over (Australian Bureau of Statistics, 2017). Imprisonment also has a disproportionate impact on the economically disadvantaged. In the UK, prisoners are more likely to come from backgrounds of poverty and interrupted education (Social Exclusion Unit, 2002) and a range of studies suggest that prisoners' families are more likely to have lower socio-economic status and be contending with a range of associated problems (see Condry 2007; Comfort, 2008; Wakefield and Wildeman, 2014, Minson, 2020).

Gender disadvantage is also perpetuated. Family members supporting prisoners are usually female (Christian, 2005; Condry, 2007; Codd, 2008; Comfort, 2008, Granja, 2016), and this brings with it a burden of care. These women will already be contending with patterns of gender oppression, 
such as the 'feminisation of poverty', or deprivations of opportunities and capabilities (Nussbaum, 2011). The work of caring for a prisoner (visiting, shopping, liaising with legal authorities) can be burdensome and like other feminised care work, is often taken for granted (Condry, 2007; Jardine, 2017). Patterns of pre-existing disadvantage and marginalisation are complex and interrelated and will intersect in particular ways for individual prisoners' families.

The experience of the harms described and repeated negative interactions with criminal justice agencies communicate powerful political messages to families of offenders about the power of the state and the protections it offers, which influence their willingness to take part in civic life and their views about government. In the US, Lee, Porter and Comfort (2014) show that mass incarceration has erected extra barriers to citizen engagement for families. Full citizenship requires both political participation and a perception that the state is legitimate and fair, both of which are transformed by the experience of having a family member imprisoned. The transformation occurs indirectly via the transmission of behaviours and attitudes from the incarcerated loved one to other family members and directly through a partner's or child's own experiences with the correctional system. As Lee et al. have shown, children of incarcerated parents are less civically engaged than other children of similar backgrounds, being less likely to be registered to vote, less likely to have voted in the last presidential election, less likely to engage in community service, express lower trust in government, and are more likely to perceive discrimination. This perpetuates across the generations leaving a section of society marginalised and excluded from civic life with important implications for the democratic process (Lee et al., 2014).

Lee et al. argue that the disparaging treatment of families by correctional authorities wears down their belief in the fairness of the wider system of government leading to a perception that all state entities are adversarial and unconcerned with the well-being of poor and ethnic minority populations. In Scotland, research on prisoners' families has found repeated negative interactions between families and prison staff that risk the creation (or entrenchment) of oppositional relationships between marginalised communities and the criminal justice system, causing damage to the perceived legitimacy of the criminal justice system amongst some of Scotland's most deprived citizens (Jardine, 2019). In work on prisoners' children in Europe, Smith describes an 'upside-down world' in which state representatives become enemies instead of sources of support as children's sense of trust and legitimacy is eroded through their interactions with criminal justice 
agencies (Smith, 2014). Minson's work with children of imprisoned mothers found the same effects on children's perceptions of the police in England and Wales (Minson 2020).

These patterns of marginalization and exclusion from civic life can be understood as part of a recasting of the relationship between the carceral state and 'custodial citizens' (Lerman and Weaver, 2014), a sizeable and growing group of individuals whose contact with the state is primarily through the institutions of criminal justice rather than democratic processes. This group comprises those who experience contact with the criminal justice system, from police surveillance and searches, to the raiding of apartment blocks, to various forms of punishment including incarceration. Many of these custodial citizens will be innocent, yet their sense of government and their place within society is mediated through the carceral state. ${ }^{1}$ Lerman and Weaver argue that custodial citizens experience a 'state-within-a-state' (2014: 8) as they are systematically denied the basic rights of full and equal citizenship, with devastating consequences for political inequality. Families of prisoners may not automatically become 'custodial citizens' through their kin relationship to an offender, but might well be part of the same socioeconomic and racially defined communities that are subject to suspicion and may experience many of the consequences of custodial citizenship through their kin relationships to a custodial citizen (which could be defined as custodial citizenship by-proxy).

Although these harms are not the intended outcomes of punishment by imprisonment, they have been allowed to 'silently ride along with those who have done time' (Wakefield et al.2016). But can these harms be justified if experienced by citizens who have done no wrong and who are not the subject of punishment? If suffered by a non-offending person we would perceive these consequences to breach human rights, contravene our understandings of citizenship, and be manifestly unjust. Yet they are commonly experienced by family members of those who have been imprisoned.

As these harms follow from punishment, even though they are not legally imposed punishment, they ought to be given full consideration within punishment theory: first because they are

\footnotetext{
${ }^{1}$ It is sometimes the case that family members are also subject to punishment when a child offends. In the UK a parent may be subject to a 'Parenting Order' when their child commits a criminal offence and there are other examples of parents being made legally accountable in other jurisdictions. However, for the purposes of this paper we are focusing on the family experience when no other family member is subject to punishment from the criminal courts linked to the offence of their family member.
} 
significant and serious, and second because they breach the rights of citizens who are innocent of wrong-doing. They therefore require justification that is independent of the punishment that gave rise to them and we will argue the state has a duty to consider whether it has 'residual obligations' (Bulow, 2014) towards these families to mitigate these harms. As researchers have looked for ways to both describe and analyse the harms several different terms have come into common useage: collateral consequences, secondary punishment, vicarious or referred pains of imprisonment, and punishment drift have all been used. It is our contention that as the field extends, our terminology needs to develop to keep up with our increased understanding of the impacts of family member imprisonment on non-imprisoned relatives. We now turn to the limitations of current terms, before suggesting a new conceptualisation to aid future analysis.

\section{Collateral consequences}

The most widely used term for the effects of imprisonment on families is 'collateral consequences' (Kirk and Wakefield, 2017; Brew, Goldman, Wildeman, 2017; Turanovic et al, 2012; Codd, 2008; Christian, 2005Hagan and Dinovitzer, 1999). Scholars write of 'a burgeoning literature' documenting 'the collateral consequences of mass incarceration on the families' of prisoners (Brew, Goldman and Wildeman, 2017). The term is used to capture the entirety of the experiences of those whose family member is imprisoned which may include, but are not limited to, family disruption, emotional difficulties, financial difficulties, the burden of child care, the breakdown of social networks, and disrupted home and working environments (Turanovic et al, 2012).

Useful as this term has been there are three reasons why scholars should look beyond it. Firstly, the term 'collateral consequences' has long been used by punishment theorists to describe secondary effects of punishment on the offender. It relates particularly to civil disqualifications which impact upon a person who has served a period of imprisonment such as disenfranchisement, exclusion from employment, or restriction of welfare support (Burton, Cullen, Travis, 1987; von Hirsch and Wasik, 1997; LaFollette, 2005; Hoskins, 2016). When searching for articles on 'collateral consequences' there are a mix of articles on post-release consequences for the offender, and the consequences, both during and after release, for the family members of prisoners. Confusingly, the term may be used to mean either, and occasionally both, within the same piece of writing (Rodriguez and Turanovic, 2018). We contend that the term is most suited to post 
conviction consequences for offenders because in that context the consequences really are collateral; they are not the primary intention of the punishment, but are secondary consequences which follow, either in parallel or sequentially. The collateral consequences for prisoners may well have further harmful effects for families (e.g. financial difficulties due to restricted employment possibilities), but this is not what the term refers to in punishment theory.

Secondly, the term is problematic because the word 'collateral' has two different meanings. The first, according to the Oxford English Dictionary, is adjectival, describing something 'additional but subordinate; secondary'. If that is the assumed meaning when attached to the consequences to family members of imprisonment, it implies that those impacts are secondary to the imprisonment and are not worthy of being addressed in their own right. The second meaning of 'collateral' is to be 'situated side by side; in parallel'. Its origins suggest this more neutral meaning (Late Middle English (as an adjective): from collateralis: col- 'together with' + lateralis (from latus, later- 'side'). If collateral is understood as 'side by side' then the descriptor of 'collateral consequences' will not necessarily reduce the harms to secondary or subordinate. However, the harms to prisoners' families do not progress in parallel to a prisoner's experience, instead they are a causal consequence of the offender's punishment and interwoven into the families' lives, with a mutual and constantly evolving relationship between the prisoner and their family. Although the lack of clarity in the terminology has been acknowledged (e.g. Kirk and Wakefield, 2017; Lipkke 2016), there is not yet consensus on its meaning and certainly if collateral is understood as 'secondary' it does not capture the relationship of the harms to the imprisonment in a way that affords them consideration within punishment theory and literature.

Thirdly, 'collateral consequences' and the sometimes interchangeable term 'collateral damage' (e.g. Foster and Hagan 2009; Gust, 2012) limit consideration of the harms to families because of the history of the term 'collateral damage'. It was first used by the US military in the Vietnam War to describe the US-caused deaths of civilians, in order to 'deflect atrocity' (Perice, 2007); its acceptance and usage linked the military terminology and strategy to changes in social policy which allowed groups of people to be categorized as unwanted, surplus, or unnecessary. In accepting the rationale behind 'collateral damage' militarily and societally, collateral damage, becomes not simply a by-product, but part of the assumed and accepted consequence of any 'progressive' action: 
"By cultural constructions of worthy and worthless lives we justify social policies and military actions that multiply death and misery...The same cultural processes ... are at work in the appalling social policies enacted by the ruling elite in America based upon a cultural arrogance to declare war on those considered part of the superfluous population." (Perice, 2007: 115)

By using the term 'collateral consequences' when referring to harm to families of prisoners are we (perhaps unintentionally) implying that the harms are the unfortunate consequence of having been born 'too close to the battlefield' (Perice, 2007: 120)? Are families of prisoners perceived as a superfluous population whose lives have less worth than those whose family members have not offended? Families might at times be perceived as 'surplus people' in the project of punishment, but they are clearly more than this. The term 'damage' as a static conceptualisation also ignores a wider range of negative consequences across time and place (a point to which we will return). We have ourselves used the term 'collateral damage' in a previous publication (Condry, Kotova and Minson, 2016) but, on reflection we question whether it can help us to fully make sense of the harms experienced by families, or the responsibilities of the state to recognise and respond to these consequences.

To summarise, there are a number of problems with the term 'collateral consequences': it is conceptually opaque, conflating the experiences of two separate groups (prisoners and their families); multiple meanings of the word collateral may mean it is differently interpreted and understood; and it can be marginalising - the language used to describe these effects may have contributed to their neglect by punishment theorists, implying they are incidental to the real business of punishment.

\section{Secondary punishment}

The word 'punishment' has often been linked to the experiences of families of prisoners, for example a book on the 'collateral consequences of mass imprisonment' (Mauer and Chesney-Lind, 2002) is titled 'Invisible Punishment', and Smith's book on the experiences of children of prisoners is called 'When the innocent are punished' (2014). Prisoner's families are said to be serving a 'parallel sentence' (Granja, 2016), and Comfort writes of both 'secondary prisonization' (2007) and 'punishment beyond the legal offender' (2009). In none of these instances do the authors argue 
that the harms experienced are 'punishment' in the legal sense, nor that the harms experienced by the families form part of the punishment of the offender or are justified as punishment. Instead, they use the word punishment, or write about families being 'sentenced', to draw attention to the fact that it is 'as if' the families are being punished,

"Thus, co residents are de facto subjected to the same processes and regulations as the supervisee, inspiring feelings of being intruded upon, monitored, and controlled as if they, too, were officially sanctioned." (Comfort, 2008, emphasis added).

These writers draw upon detailed empirical research on the experiences of families affected by imprisonment who themselves talk about the punishment which they feel has been extended to them. In a study on families taking care of the children of mothers in prison one grandmother said, 'I say it's a sentence for me. In fact, it's more of a sentence for me than it is for my daughter' (Minson, 2020). What is expressed is the sense that the effects of imprisonment on family members are 'punishing' and are felt or experienced - often acutely - as punishment. There is no doubt that families of prisoners are subjected to penal regulations when they enter prisons, and some of these measures may be coercive - for example, over-zealous searching or regulation of clothing. They may also be subject to stigma, shame, and other negative consequences (Condry, 2007). However, these experiences cannot be described as legal punishment, or an official sanction following a crime, though they do testify to the very close relationship between punishment and the harms experienced by the families of prisoners. However, this must be distinguished from 'punishment': "Pain, coercion, repression, deprivation and exclusion are all common characteristics of punishment but they are not synonymous with it and nor are they justified as punishment." (Zedner, 2016: 6)

The term punishment, although an 'essentially contested concept' (Zedner, 2016: 4), is widely accepted to consist of a number of key elements, including the intentional administration of consequences considered unpleasant to an offender for his offence. For punishment to be justified it must be imposed and administered by an authority constituted by a legal system against which the offence is committed (Hart, 2008:4). Of the utmost importance is the understanding that 
punishment is the imposition of suffering on a wrongdoer, and the innocent ${ }^{2}$ cannot be punished as 'the infliction of suffering on a person is only properly described as punishment if that person is guilty' (Quinton, 1954). Although harms to families cannot be regarded as punishment, as the harms are not due to punishment for an offence committed by the family members but are attributable to punishment of a relative, the term punishment is often used in conjunction with the harms suffered by prisoners' families. This is indicative of the complex interaction between harms and punishment. The use of language such as the 'unintentional burdens of punishment' (Kolber, 2012) when referencing harms to prisoners' families, suggests that punishment theorists have recognised that the harms to families are in some way ancillary to punishment, but they have not incorporated them into broader discussions of punishment nor have they discussed how such harms can be justified or understood. The experiences of prisoners' families may partly have been excluded from wider theoretical reasoning because labelling them 'punishment' is a misnomer.

There are two notable exceptions to the neglect of penal harms to prisoners' families from Bulow (2013) and Lipkke (2017) who analyse the effects on families within the framework of moral philosophy and punishment theory. Bulow's concern is that the harms of imprisonment to the close family members and children of prison inmates may give rise to special moral obligations towards them. He uses the terms 'collateral harms' and 'collateral consequences' and focuses on whether the harms that flow from punishment to families can be morally justified. He argues that imprisonment should only be used as a last resort, but where it is necessary it should give rise to special moral obligations towards children and families of prisoners, a point to which we return below. Lippke characterises the effects of legal punishment on families as 'punishment drift' and similarly to Bulow, argues that efforts ought to be made to limit or ameliorate it. He argues that 'failure to confine punishment drift comes perilously close to punishment of the innocent and is at odds with other legal doctrines and broader penal practices that hold offenders, and offenders alone, responsible for their crimes" (Lipkke 2017: 645); however, "punishment drift cannot be analogized to the deliberate punishment of the innocent' (2007: 651). We agree with this contention but suggest that 'punishment drift' does not capture the relational, mutual, agentic, nonlinear, and heterogenous qualities that are outlined below.

\footnotetext{
2 The word 'innocent' is used to mean that they have not been found guilty of a criminal offence for which they are receiving state sanctioned punishment.
} 


\section{Referred and direct 'pains of imprisonment'}

Sykes (1958) described the 'pains of imprisonment' as the deprivation of liberty, goods and services, heterosexual relationships, autonomy and security. In later work prison sociologists have drawn upon the metaphors of 'depth'(Downes, 1993) 'weight' (King and McDermott, 1995) and 'tightness'(Crewe, 2011) and more recently they have also been applied, under the metaphor of 'breadth' (Cohen, 1985), to prisoners' family members (Comfort, 2008; Murray et al, 2014; Aiello and McCorkel, 2017; Kotova, 2018; Lanskey et al, 2018). Depth, weight, tightness and breadth are useful concepts for categorising or describing the experiences of families and provide a helpful characterisation of the ways in which certain aspects of imprisonment are also experienced by families, however, we suggest a new way of understanding these pains as harms characterised by fluidity and complexity, filtered through interpersonal relationships.

\section{Symbiotic harms}

There is a need for a new conceptual and analytic terminology which will allow the consequences of imprisonment on family members to be better understood and critically examined by sociologists and punishment theorists in this growing field of study. We suggest that the effects of punishment on families are better described as 'symbiotic harms', negative effects that flow both ways through the interdependencies of intimate associations such as kin relationships exhibiting five key characteristics: they are relational, mutual, non-linear, agentic, and heterogeneous. Calling them symbiotic 'consequences' (or indeed 'effects') would not capture these characteristics - its neutrality requires the qualifier of 'negative'. Instead the term 'harms' captures the severity and gravity of the impacts. Of course, there are some families who experience relief and even improvement in their lives when a problematic or harmful member is imprisoned, for example a violent or drug abusing partner or parent (Smith, 2014; Turney, 2015; Wakefield and Wildeman, 2014; Wakefield and Powell, 2016). The argument could be made that retaining a neutral term such as 'effects' or 'consequences' would allow us to better capture this range of experience. However, this does not do justice to the seriously harmful effects experienced by most families most of the time. A focus on both individual and social harm (Hillyard, 2004) allows us 
to capture a wide range of effects and to consider harm that results from the exercise of state power, which can remain hidden with a narrow focus on crime. Hillyard and Tombs (2008) argue that criminalisation and punishment inflict pain on the individual being punished, and 'these very processes create wider social harms which may bear little relationship to the original offence and pain caused' (2008: 11).

'Symbiotic' points to the interdependent and mutual characteristics of relationships, where individuals are dependent upon and receive reinforcement, whether beneficial or detrimental, from each other. Harms are symbiotic when they are enmeshed and entwined within connections to others and are more than vicarious - the experience of the harms is altered by the symbiosis. Symbiotic harms could describe negative effects that filter through other relationships outside imprisonment, for example for families experiencing mental illness or drug addiction and interaction with health services. But in the context of the state removal of an individual's liberty they take on particular forms that need justification in their own right.

\section{i) Relational}

A relational perspective acknowledges that kin relationships weave their way through a prison sentence. Prisoners' families are enmeshed in relationships with their loved one in prison, with other family members, and have a relationship of sorts with state institutions of punishment. A family member's interaction with prison, and their experiences of the broader harms that flow from punishment, are filtered through the prism of their kin relationship and are interactive. A relational perspective therefore has three aspects: a) a focus on the human lives and kin relationships of the people involved; b) a focus on the relationship (of both the prisoner and the family member) with state punishment, the institution of the prison, and its actors; and c) an understanding of how the two filter through each other, and how they are central to identity and personhood. This resonates with Carol Smart's conception of the relationality and connectedness of personal life and how personal life is embedded in social relationships (Smart, 2007). A relational perspective recognises the significance of relationships to identity and our own sense of personhood. Lives are interwoven and embedded at a material, emotional, and metaphorical level and do not simply end when an individual is removed from the family home, or indeed with the termination of an intimate relationship through divorce or death. We continue to carry our histories, our biographies, and emotions and, as Smart describes, family bonds have tenacity and become 'part of one' (Smart 
2007). A relational perspective therefore goes beyond a snapshot of interactions in the prison visits room and understands relationships as part of the everyday lives of families and of prisoners. Some relationships won't even involve direct interaction - children who are not taken to visit a parent, for example, are often still profoundly affected by their incarceration, with effects resonating across the lifecourse (Wakefield and Wildeman, 2014).

This long-term perspective in also vital as relationships may pre-exist the sentence, be maintained throughout a sentence, and continue when a prisoner is released. It is important to recognise how symbiotic harms flow through vertical as well as horizontal relationships, and that they can even continue across generations, with serious effects on the adult children of prisoners (Wakefield and Wildeman, 2014) and intergenerational trauma and loss (Halsey, 2017).

\section{ii) Mutual}

Symbiotic harms are further characterised by mutuality. This is sometimes neglected or not made explicit in the literature on prisoners' families which tends to focus on the effects on families and to consider the prisoner only when they appear in the visits room. Yet harms may be either mitigated or worsened when they are negotiated and experienced through relationships. At a basic level, prisoners and their families are affected by what happens to each other - what happens to the prisoner affects his or her family, and what happens to the family affects the prisoner and this will be an ongoing, negotiated process. For example, harms can be intensified when families worry about prisoners and this in turn affects their wellbeing. Imprisoned parents worry about children on the outside. Financial strain caused by the removal of the family member to prison impacts upon the family but also causes strain if they are unable to provide money for visits or telephone calls, and this in turn affects the prisoner. It may be that symbiotic harms are lessened or mitigated by supportive relationships, and this support can flow both ways, as has been recognised in recent prison programmes that seek to encourage prisoners who are parents to support their children from the inside (e.g. Safe Ground, 2017). Mutuality could be seen to some degree to fit within the wider category of 'relationality' - however, separate recognition is useful as the focus here is on how each aspect of a prison sentence (and indeed the arrest, court hearing, release, and so on - see Condry and Smith 2019) is experienced mutually and it is therefore useful to ensure the scope of analysis is wide enough to include it. Mutuality is also an important element of larger and more 
diffuse symbiotic harms producing social injustice and inequality, damage to citizenship, and the breaching of human rights, which are also mutually reinforcing processes. To take one example, the disenfranchisement of an individual prisoner could be understood as the relationship between a single person and the state and the denial of their democratic rights. Yet in Lee et al.'s study outlined above, partners and children also experience barriers to citizen engagement, which occur indirectly through the transmission of behaviours and attitudes from the incarcerated loved one and directly through negative encounters with the correctional system (Lee et al. 2014). Civic disengagement is experienced mutually and relationally across time.

\section{(iii) Non-linear}

The characterisation of harms as 'collateral' suggests that they are situated side by side, running in parallel on a unidirectional, linear trajectory. A family member is given a prison sentence, this in turn has negative consequences for his or her relatives, and these consequences must be borne alone on the outside in parallel with the prisoners' own difficulties on the inside. Symbiotic harms better captures the messiness of the reality of relationships and lived experience; the harms experienced by families and by prisoners do not run alongside each other but interact and interrelate in complex ways and will be experienced differently by different people. Relationships evolve with constant negotiation, a two-way, co-active construction with ebbs and flows, interwoven across time. Relationships end or are rekindled; they may involve frequent visits or letter writing, or periods where there is no contact; they may be happy and fulfilling, or sad and exhausting; they may be intimate, or distant. Very likely they will move between different points at different times. Similarly, harms themselves are non-linear and may vary in character and intensity across the course of a prison sentence and on release. In a recent chapter, Comfort reflects upon the challenge, frustration, and disappointment that can accompany a male prisoner's return to the family home. She shows how, in contrast to expectations, the post-release period is rife with complex emotions, interpersonal conflict, and a pervasive feeling of being let down - by oneself, one's partner, and society at large. Her analysis shows that gender roles and their renegotiation on release often lie at the heart of the challenges faced (Comfort 2018). Re-entry, then, is not a simple linear process and it can take considerable effort to build and reconfigure kin relationships and domestic responsibilities. 
(iv) Agentic

'Collateral' harms suggest that consequences happen to families, and constructs them as passive recipients of those effects, neglecting the agency of family members and their role in negotiating the process of punishment harms. What family members do with the situation in which they find themselves is important. How do they construct relationships through imprisonment? Are some family members more vulnerable to harm than others? What aids resilience and resistance to some of the damaging effects? Many excellent empirical studies of families of prisoners delve into this negotiated reality and do far more than catalogue the difficulties families face, and we argue that the concept of symbiotic harms allows us to better define the levels of fine distinction they provide. Jardine draws upon Finch's theory of family practices and argues that the family relationships

affected by imprisonment are not only highly individual, but also actively constructed through embodied displays of care and commitment (Jardine, 2017). Family members are not just 'going through the motions' of supporting a prisoner, but actively construct and reconstruct their relationships through imprisonment (Comfort 2008). Family members are therefore agentic actors who make decisions, manage problems, negotiate relationships, and choose to act in particular ways.

\section{(v) Heterogeneous}

To characterise harms as symbiotic helps to capture their fluid, constructed qualities and the ways in which they flow from human relationships. As such, they are experienced in very individual ways by prisoners' families. Although their experiences are often described collectively, prisoners' families are not a monolithic group and more recent literature has begun to delineate some of their experiences. One useful way to identify some of these differences is to distinguish between mediators and moderators of experiences (Murray et al, 2014; Foster and Hagan, 2015). Moderators might exacerbate or alleviate the effects of imprisonment on families and could include resilience; gender and ethnicity; or support received from state or voluntary agencies. Mediators are co-producers of effects such as stigma, guilt and shame, the offence type, criminal justice practices, and prison regimes (Condry and Smith 2018). Furthermore, the category of prisoners' families encompasses a range of kin relationships; the experience of a child whose primary carer is imprisoned is likely to differ considerably from a mother whose son is imprisoned (McCarthy 
and Adams 2017; Gueta 2018). There are, therefore, numerous dimensions which lead to a variety of different family experiences.

\section{Conclusion - the advantages of 'symbiotic harms'}

In this paper we have drawn upon a rich and fertile body of previous work on prisoners' families to suggest a new approach that might offer a number of advantages. This is not meant to be prescriptive, definitive, or to suggest that previous body work is in some way lacking. We do critique, however, the terms currently in use to describe the effects of punishment on families. The language of 'symbiotic harms' offers greater conceptual precision, and recognition of the devastating harm wrought by imprisonment and its expansion. This approach will provide useful tools for future empirical research and will sensitise researchers to the need to explore and investigate the different aspects of symbiotic harms when examining the effects of imprisonment on families. It should also highlight the importance of research methods that seek to capture the meanings that family members attach to their circumstances and the ways in which they respond to them. Much of the research on prisoners' families has relied on methodologies which provide a 'snapshot' and may not capture the full picture. Single time point interviews with family members or the incarcerated person, or observations of visits within the prison environment might not be sufficient to explore the complexity of the symbiotic harms experienced. There is a need for alternative methodological approaches which are not limited to single time points, and which include multiple viewpoints from both within and outside the prison. The Families and Imprisonment Research Study (FAIR Study) is a good example of this type of multi-dimensional approach examining the experiences of families across time (Lanskey et al, 2015; 2016) and social network analysis, as used by Kreager et al (2016) enables consideration of the relationships prisoners have with others and how they might change across time. Innovative methodological approaches such as these might better capture the symbiotic nature of the harms of a family member's incarceration.

By establishing the link between punishment of an offender and the experiences of their nonimprisoned family members, harms to families can more easily be included in punishment theory. Although symbiotic harms are not punishment, nor an intended consequence of the punishment, they affect the offenders' family members only through the punishment of the offender. As has 
been argued above, there is a symbiotic relationship between the prisoner, the family and the punishment, and therefore within discussions of the reach and purposes of punishment these widereaching harms must be acknowledged. As Maruna has argued: 'It is impossible to isolate punishment as practiced in most societies to a single individual, when we are all connected in families, communities and societies.' (Maruna, 2016). Coercive measures need justification in their own right if they are not justified as punishment (Zedner, 2016), and every person has a prima facie moral right not to be harmed. Therefore, any act which causes extensive infliction of harm 'stands in need of a grounding reason which explains why such harm is morally justified' (Bulow, 2014:785). When the seriousness of these harms is recognised, and acknowledged not to be part of legally justified 'punishment' but instead a breach of the rights of citizens who are innocent of wrong-doing, punishment theorists will have to wrestle with the issue of justification and the place of symbiotic harms within punishment theory.

The argument may be made that despite the harms to innocent family members, offenders must still be imprisoned - but that does not negate the need to recognise the rights of innocent citizens, even if the imprisonment of convicted offenders can be justified. There are often competing rights, but when a right takes priority it does not remove the other right, but can be said instead to override it, and breach is therefore permitted. Bulow questions whether, when imprisonment is used as punishment, consideration should be given to the question of whether 'residual obligations' arise from the breach of duties towards innocent citizens who are harmed by it (Bulow, 2014). Residual obligations to families of prisoners could include financial help, assistance in housing, support in education, better provision for prison visits, family therapy to assist with re-integration on release, or any other measures which would reduce the harmful impact of the imprisonment on the family. In this respect we can go full circle and adopt the lessons learned from the original military use of the term 'collateral consequences. The principle now observed is that war should not harm innocents, and, if it does, then compensation is necessary (Manning, 2011). In response to the recognition that innocent parties should not be disregarded when punishment is necessary, the US justice department in 2006 recommended that deferred prosecution could be appropriately used in the case of corporations because of the collateral damage of prosecution to third parties such as shareholders, customers, and employees (Manning, 2011:278). If this can be done for shareholders and customers in the corporate sector, perhaps similar steps could be taken to protect the interests 
of family members? Greater clarity in defining the symbiotic harms experienced by families will aid in defining what residual obligations might look like and how exactly they might be addressed. Lipkke (2017) points to the obstacle of the burden to the tax payer of trying to ameliorate the

effects of punishment on families, particularly when the institutions of punishment are already burdensome and the beneficiaries would be the poor, African-American, and Hispanic, 'and thus persons about whose welfare many tax payers in the United States seem, at best, to be indifferent' (2017: 559). Understanding effects as symbiotic harms, rather than collateral, or incidental, might give greater weight to the arguments for doing so.

In conclusion, our aim has been to explore the character and depth of the effects of imprisonment on families of offenders, and we have sought to do this using a new concept of symbiotic harms. We have chosen to depart from the traditional description of the effects on these relatives as 'collateral' as it is at best insufficient and confusing, and at worst subordinating and marginalising. The reach of symbiotic harms is vast - the families of prisoners number several million in the US, and hundreds of thousands in the UK and other European countries. This includes a range of kin relationships, from birth families - parents, siblings, aunts and uncles - to partners and children of male and female prisoners. Symbiotic harms threaten social justice, human rights, and the democratic organisation of society and ought to be central to any endeavour to theorise the social ramifications of prison and punishment.

\section{Acknowledgements}

The authors would like to thank Ian Loader, Sara Wakefield, Lucia Zedner, and the journal's anonymous reviewers for their helpful and incisive comments on earlier versions of this article. 


\section{References}

Aiello, B. L., \& McCorkel, J. A. (2018) “'It will crush you like a bug': Maternal incarceration, secondary prisonization, and children's visitation." Punishment \& Society, 20(3), 351-374.

Arditti, J (2012) Parental incarceration and the family: Psychological and social effects of imprisonment on children, parents, and care-givers. New York: NYU Press.

Ashworth, A, Zedner, L (2014) Preventive Justice. Oxford: Oxford University Press.

Australian Bureau of Statistics (2017) Prisoners in Australia, 2016 http://www.abs.gov.au/ausstats/abs@.nsf/mf/4517.0 (Accessed 5th July 2017).

Beckett, K. \& Murakawa, N. (2012) 'Mapping the shadow carceral state: Toward an institutionally capacious approach to punishment' Theoretical Criminology 16(2) 221-244

Besemer, K., \& Dennison, S. (2017) Social exclusion in families affected by paternal imprisonment. Australian and New Zealand Journal of Criminology, 1-18.

Braman, D (2004) Doing time on the outside: Incarceration and family life in urban America. Ann Arbor, MI: University of Michigan Press.

Brew, B., Goldman, A., Wildeman, C. (2017) 'The effects of corrections on communities and families', in Routledge Handbook of Corrections in the United States (eds.) Hayden Griffin, O and Woodward, V.H., Abingdon: Routledge

Burton, V.S., Cullen, F.T., Travis, L.F. (1987) The Collateral Consequences of a Felony Conviction: A National Study of State Statutes, 51 Fed. Probation 52

Bulow, W (2014) The Harms beyond Imprisonment: Do we have special moral obligations towards the families and children of prisoners? Ethical Theory and Moral Practice, 17 (4), 775 789.

Christian, J (2005) Riding the Bus: Barriers to Prison Visitation and Family Management Strategies. Journal of Contemporary Criminal Justice, 21(1), 31-48.

Clemmer, D (1958) [1940]. The Prison Community. New York, NY: Holt, Rinehart and Winston. 
Codd, HL (2008) In the Shadow of Prison: Families, Imprisonment and Criminal Justice. Devon, UK: Willan Publishing.

Comfort, M (2003) In the tube at San Quentin: The 'Secondary Prisonisation' of women visiting inmates. Journal of Contemporary Ethnography, 32 (1), 77-107.

Comfort, M et al (2005). "You can't do nothing in this damn place": Sex and intimacy among couples with an incarcerated male partner. Journal of Sex Research 42 (1): 3-12.

Comfort, M (2007) Punishment beyond the legal offender. Annual Review of Law and Social Science 3:271-96.

Comfort, M (2008) Doing Time Together: Love and Family in the Shadow of Prison. Chicago: Chicago University Press.

Comfort, M (2018) ' I'm the man and he's the woman!': Gender Dynamics among Couples During and After Prison', in Condry, R. and Smith, P.S. (eds.) Prison, Punishment and the Family: Towards a New Sociology of Punishment? Oxford : Oxford University Press.

Condry, R. (2007) Families Shamed: The consequences of crime for relatives of serious offenders. Devon: Willan

Condry, R., Kotova, A., Minson, S.(2016)_Social Injustice and collateral damage: the families and children of prisoners'in Jewkes, Y., Bennett, J., Crewe, B. (ed). Handbook on Prisons, Routledge

Condry, R., (2018) 'Prisoners' families and the problem of social justice' in Condry, R., and Smith P.S., (eds.) Prisons, Punishment and the Family: Towards a New Sociology of Punishment ? Oxford: Oxford University Press

Condry, R. and Smith, P. (2019) 'A holistic approach to prisoners' families - from arrest to release', in Hutton, M. and Moran, D. (eds.) The Palgrave Handbook of Prison and the Family, Palgrave Macmillan

Crewe, B (2011) Depth, weight, tightness: Revisiting the pains of imprisonment, Punishment and Society, Vol 13, Issue 5, pp. $509-529$. 
Cunningham, A, Baker, L (2003) Waiting for Mommy: Giving a Voice to the Hidden Victims of Imprisonment. Ottawa: National Crime Prevention Centre.

Dallaire, D, Wilson, L. (2010) The relation of exposure to parental criminal activity, arrest, and sentencing to children's maladjustment. Journal of Child and Family Studies, 19(4), 404-418.

Foster, H and Hagan, J (2009) The Mass Incarceration of Parents in America: Issues of Race/ Ethnicity, Collateral Damage to Children, and Prisoner Reentry, The ANNALS of the American Academy of Political and Social Science 623 (1): 179 - 194.

Foster, H and Hagan, J (2015) Punishment Regimes and the Multilevel Effects of Parental Incarceration: Intergenerational, Intersectional, and Interinstitutional Models of Social Inequality and Systemic Exclusion, Annual Review of Sociology 41, 135-158.

Garland, D (1990) Punishment and Modern Society: A Study in Social Theory. Oxford: Clarendon Press.

Granja, R (2016) Beyond prison walls: The experience of prisoners' relatives and meanings associated with imprisonment Probation Journal Vol. 63(3) 273-292.

Gueta K (2018) The experience of prisoners' parents: A meta-synthesis of qualitative studies. Family Process, 57: 767-782

Gust, L V (2012), Can Policy Reduce the Collateral Damage Caused by the Criminal Justice System? Strengthening Social Capital in Families and Communities. American Journal of Orthopsychiatry, 82: 174-180.

Hagan, J, Dinovitzer, R (1999) Collateral consequences of imprisonment for children, communities and prisoners. Crime \& Justice, 26, 121.

Hagan, J, Foster, H, (2012) Children of the American Prison Generation: Student and School Spillover Effects of Incarcerating Mothers. Law \& Society Review, 46 (1), 37-69.

Halsey, M. and Deegan, S. (2015) 'Picking up the pieces': Female significant others in the lives of young (ex)incarcerated males, Criminology and Criminal Justice 15 (2): 131-151 
Halsey, M (2017) Child Victims as Adult Offenders: Foregrounding the Criminogenic Effects of (Unresolved) Trauma and Loss, British Journal of Criminology, online first Jan 2017, 58 (1): 1736

Hart, HLA (1959) Prolegomenon to the Principles of Punishment Proceedings of the Aristotelian Society, N.S. Vol. LX.

Hillyard, P, et al (eds.) (2004) Beyond Criminology: Taking Harm Seriously. London: Pluto Press. Hillyard, P and Tombs, S (2008) Beyond criminology? in Dorling et al, Criminal obsessions: Why harm matters more than crime. Centre for Crime and Justice Studies. https://www.crimeandjustice.org.uk/sites/crimeandjustice.org.uk/files/Criminal\%20obsessions.p $\underline{\text { df }}$

Hoskins, Z (2016) 'Collateral Restrictions' in Flanders, C, Hoskins, Z (eds.) The New Philosophy of Criminal Law. Rowman: Littlefield International.

Jardine, C (2017) Constructing and Maintaining Family in The Context of Imprisonment, British Journal of Criminology, 58, 1, 114-131,

Jardine, C (2019) Families, Imprisonment and Legitimacy Abingdon: Routledge

Kirk, DS, Wakefield, S (2017) Collateral Consequences of Punishment: A Critical Review and Path Forward. Annual Review of Criminology.

Kolber, AJ (2012) Unintentional Punishment, 18 Legal Theory 1.

Kreager, D., Schaefer, D. ,Bouchard, M., Haynie, D., Wakefield, S., Young, J., Zajac, G. (2016) “Toward a Criminology of Inmate Prison Networks." Justice Quarterly 33, 6: 1000-1028.

LaFollette, H (2005) Consequences of Punishment: Civil Penalties Accompanying Formal Penalties, Journal of Applied Philosophy 22(3): 241-261.

Lanskey, C., Lösel, F., Markson, L., \& Souza, K. (2016). Children's contact with their imprisoned father and the father-child relationship after his release. Families, Relationships and Societies, $5(1), 43-58$. 
Lanskey C., Lösel. F, Markson, L., \& Souza, K. (2015). Re-framing the analysis: a 3-dimensional perspective of prisoners' children's well-being. Children and Society, 29(5), 484-494.

Lee, H, Porter, LC and Comfort, M (2014) Consequences of Family Member Incarceration: Impacts on Civic Participation and Perceptions of the Legitimacy and Fairness of Government. ANNALS of the American Academy of Political and Social Science, 651: 44-73.

Lee, H, McCormick, T, Hicken, M, \& Wildeman, C (2015) Racial Inequalities in Connectedness to Imprisoned Individuals in the United States. Du Bois Review: Social Science Research on Race, 12(2): $269-282$.

Lippke, R.L. (2017) 'Punishment Drift: The Spread of Penal Harm and What We Should Do About It' Criminal Law and Philosophy, 11: 645-649

Lopoo, L M, and Western, B (2005) 'Incarceration and the formation and stability of marital unions'. Journal of Marriage and Family 67 (3): 721-34.

Manning, R (2011) Punishing the innocent: children of incarcerated and detained parents. Criminal Justice Ethics, 30, 267-287.

Maruna, S (2016) Commentary: Time to Get Rid of the Skid Bid? What Good Are Short Stays of Incarceration?. The Annals of the American Academy of Political and Social Science, 665(1), 98 -102 .

McCarthy D, Adams M (2017) "Yes, I can still parent. Until I die, he will always be my son": Parental responsibility in the wake of child incarceration, Punishment and Society, 21(1), 89-106 Ministry of Justice (2017) Offender management statistics quarterly: October to December 2016, Table 1.4. London: Ministry of Justice.

Minson, S., Condry, R. (2015) The visibility of children whose mothers are being sentenced for criminal offences in the courts of England and Wales. Law In Context, 32, 28-45

Minson, S. (2018) 'Direct harms and social consequences: An analysis of the impact of maternal imprisonment on dependent children in England and Wales', Criminology and Criminal Justice, 19(5), 519-536 
Minson, S. (2020) Maternal Sentencing and the Rights of the Child Hampshire: Palgrave

Murray, J, Farrington, D (2008) Effects of Parental Imprisonment on Children. In Tonry, M (Ed.), Crime and Justice: A review of research (vol 37.) (pp.133-206) Chicago, IL; University of Chicago Press.

Murray, J et al, (2014). Effects of Parental Incarceration on Children: Cross-National Comparative Studies. American Psychological Association.

Nussbaum, M (2011). Creating Capabilities: The Human Development Approach. Cambridge Massachusetts and London: Harvard University Press.

Office for National Statistics (2012) 2011 Census: Key statistics for England and Wales, March 2011. London: Office for National Statistics.

Perice, GA (2007) The Culture of Collateral Damage: A Genealogy. Journal of Poverty, 10:4, 109123.

Prison Reform Trust, (2014) Projects and Research: Race, Prison Reform Trust website. Available at: http://www.prisonreformtrust.org.uk/ProjectsResearch/Race.

Quinton, AM (1954) On Punishment Analysis 14(6) 133-142.

Rodriguez, N., Turanovic, J.J. (2018) 'Impact of Incarceration on Families and Communities', in The Oxford Handbook of Prisons and Imprisonment (eds.) Wooldrege, J. Smith, P. Oxford: Oxford Univeristy Press

Safe Ground (2017) Fathers Inside, Safe Ground website. Available at: http://www.safeground.org.uk/programmes-services/fathers-inside/.

Sampson, R (2011) The Incarceration Ledger: Towards a new era in assessing societal consequences. Criminology and Public Policy, 10, 819-828.

Smith, S. P. (2014) When the Innocent are Punished Basingstoke: Palgrave MacMillan.

Sen, A (1999) Development as Freedom. Oxford: Oxford University Press. 
Social Exclusion Unit (2002) Reducing Re-offending by ex prisoners. London: Social Exclusion Unit.

Sykes, G. (1958) The Society of Captives. Princeton NJ: Princeton University Press

Travis, J, Waul, M (Eds.) (2004) Prisoners Once Removed: The Impact of Incarceration and Reentry on Children, Families, and Communities. Chicago: Urban Institute Press.

Turanovic, JJ, Rodriguez, N, Pratt, TC (2012) The collateral consequences of incarceration revisited: a qualitative analysis of the effects on caregivers of children of incarcerated parents Criminology 50(4), 913.

Turney, K (2015) Hopelessly Devoted? Relationship Quality During and After Incarceration, Journal of Marriage and the Family, 77, 2: 480-495.

von Hirsch, A, Wasik, M (1997) Civil disqualifications attending conviction: a suggested conceptual framework. Cambridge Law Journal, 56, 599-624.

Wakefield, S and Powell, K (2016) Distinguishing Petty Offenders from Serious Criminals in the Estimation of Family Life Effects. The ANNALS of the American Academy of Political and Social Science, 665, 195-212.

Wakefield, S, Wildeman, C (2011) Mass imprisonment and racial disparities in childhood behavioral problems. Criminology \& Public Policy, 10(3), 793-817.

Wakefield, S, Wildeman, C (2014) Children of the prison boom: Mass incarceration and the future of American inequality. Oxford: Oxford University Press.

Wakefield, S., Lee, H., Wildeman, C. (2016) Tough on Crime, Tough on Families? Criminal Justice and Family Life in America. The ANNALS of the American Academy of Political and Social Science, 665(1) 8-21

Western, B (2006) Punishment and Inequality in America. Russel Sage Foundation: New York. Young, M (1990) with new forward by Allen, D (2011) Justice and the Politics of difference. Princeton: Princeton University Press. 
Zedner, L (2016) Penal Subversions: When is a punishment not punishment, who decides and on what grounds? Theoretical Criminology 20(1) 3-20. 